\title{
First report of the presence of Trypanosoma evansi in dogs from Paraguay applying molecular techniques
}

\author{
Primeiro relato da presença de Trypanosoma evansi em cães no \\ Paraguai usando técnicas moleculares
}

\author{
Oscar Daniel Salvioni Recalde', Stefanía Fraenkel', María José Tintel², Verónica Paola Arze ${ }^{3}$ \\ Natalia Ramírez Centurión', Miriam Rolón ${ }^{4} \&$ Celeste Vega Gómez ${ }^{4 *}$ \\ 'Biologist, Molecular Biology Department, Centro para el Desarrollo de la Investigación Científica (CEDIC), Asunción, Paraguay \\ 2 Veterinarian, DSc., Biology Department, CEDIC, Asunción, Paraguay \\ ${ }^{3}$ Biotechnologist, MSc., Biology Department, CEDIC, Asunción, Paraguay \\ ${ }^{4}$ Biologist, DSc. Biology Department, CEDIC, Asunción, Paraguay
}

\begin{abstract}
Surra is a disease caused by the hemoflagellate pathogen Trypanosoma evansi which affects a wide variety of mammals. The only cases reported of the presence of T. evansi in Paraguay were identified in samples from horses and capybaras and they were detected by light microscopy in the 19th century. The aim of this study is to report three autochthonous cases of canine trypanosomiasis caused by T. evansi, for the first time in the country, using molecular techniques and their application for the differential diagnosis of trypanosomatids species. The technique implemented was real-time PCR-HRM, amplifying a fragment of the hsp70 gene, using a pair of primers initially used to discriminate Leishmania species. This is the first report on the usage of these primers to detect T. evansi through HRM analysis, which allows the differentiation of trypanosomatids species simultaneously, making it an efficient tool for differential diagnosis.
\end{abstract}

Keywords: 70kDa Heat Shock Protein (hsp70), Internal transcribed spacer (ITS1), Kinetoplastid, Surra, PCR-HRM.

\section{Resumo}

Surra é uma doença causada pelo patógeno hemoflagelado Trypanosoma evansi, parasito capaz de acometer diversos mamíferos No Paraguai, os únicos relatos que mencionam a presença de T. evansi datam do século 19, nos quais o parasito foi detectado em amostras provenientes de cavalos e capivaras. Neste sentido, este trabalho relata pela primeira vez três casos autóctones de tripanossomíase canina no Paraguai, aplicando técnicas moleculares para o diagnóstico diferencial de espécies de tripanossomatídeos. Para atingir o objetivo proposto, um fragmento do gene hsp7O foi amplificado por PCR-HRM em tempo real, empregando um par de primers inicialmente utilizados para diferenciar espécies do gênero Leishmania. O presente estudo relata pela primeira vez a utilização desses primers para a detecção T. evansi mediante a análise de HRM, a qual permite a diferenciação de espécies de tripanossomatídeos simultaneamente, tornando esta metodologia uma ferramenta eficiente para o diagnostico diferencial.

Palavras-chave: proteína de choque térmico de 70 kDa (Hsp70), Espaço Interno Transcrito (ITS1), cinetoplastídeos, Surra, PCR-HRM.

\section{Introduction}

Surra is a disease which has spread from Africa and Asia to America (Brun et al., 1998; Desquesnes, 2004) and is caused by a pathogenic hemoflagellate called Trypanosoma evansi. This parasite belongs to the order Kinetoplastida, and to the Trypanosomatidae family (Desquesnes et al., 2013b), is generally monomorphic, although it may present polymorphism sporadically (Brun et al., 1998). Morphologically, it is indistinguishable from the slim forms of the trypanosomatids T. brucei brucei, T. brucei rhodesiense, T. brucei gambiense and T. equiperdum (Brun et al., 1998).

\section{BJ $\mathrm{M}$

How to cite: Salvioni Recalde, O. D., Fraenkel, S. Tintel, M. J., Arze, V. P., Ramírez Centurión, N., Rolón, M., \& Vega Gómez, C. (2021). First report of the presence of Trypanosoma evansi in dogs from Paraguay applying molecular techniques. Brazilian Journal of Veterinary Medicine, volume, e001920. https://doi.org/10.29374/2527-2179. bjvm001920

Received: October 14, 2020.

Accepted: December 28, 2020.

\section{*Correspondence}

Celeste Vega Gómez

Molecular Biology Department, Centro para el Desarrollo de la Investigación Científica CEDIC

Manduvirá 635 entre 15 de Agosto y O'Leary Post code 1255, Asunción-Paraguay E-mail: mcvegagomez@gmail.com
Copyright Recalde et al. This is an Open Access article distributed under the terms of the Creative Commons Attribution Non-Commercial License, which permits unrestricted non-commercial use, distribution and reproduction in any medium provided the original work is properly cited. 
T. evansi is implicated in killing thousands of wild and even domestic mammals and has the widest worldwide distribution among trypanosomatids. Chronically infected animals can live for several years, but acutely infected animals die within weeks or months (Brun et al., 1998). It presents a monoxenous life cycle without this protozoan undergoing evolution between the time that elapses from transmission from one host to another. This difference, when compared to other trypanosomes that do show evolution, has been explained by the loss of the kinetoplast maxicircles in T. evansi (Borst et al., 1987; Lun \& Desser, 1995). The multiplication of T. evansi in its mammalian hosts occurs by longitudinal binary fission, and takes place blood, lymph, or cerebrospinal fluid (Fowler, 2010).

Mechanical transmission of the parasite has been mainly attributed to blood-sucking arthropods of the genus Tabanus, Stomoxys, Atylotus and Lyperosia (Brun et al., 1998). They can also be transmitted iatrogenic, vertical and orally (Desquesnes et al., 2013a). There are reports of transmission by means of blood-sucking bat bites from the Desmodus rotundus species (Desquesnes et al., 2013a), which are considered, in addition to being vectors, reservoirs and hosts (Desquesnes et al., 2013a; Herrera et al., 2005; Hoare, 1965; Woo, 1977).

The presence of T. evansi has been already reported in South America. It was detected in different animals, such as equines (Silva et al., 1995), coatis (Nunes \& Oshiro, 1990), capybaras (Muñoz \& Chávez, 2001; Stevens et al., 1989) and cattle (Franke et al., 1994). In Paraguay, in particular, there are only two reports of the presence of T. evansi, both of which were performed by light microscopy. The cases were detected in horses in 1901 (Elmassian; 1901; Elmassian 1902; Elmassian \& Migone, 1903) and in capybaras in 1910 (Migone, 1910).

There are few reported cases of dogs infected with T.evansi in South America. The reports correspond to Brazil (Colpo et al., 2005; Franciscato et al., 2007; Frankeet al., 1994; Stevens et al., 1989), Colombia (Correa-Salgado et al., 2010; Jaimes-Dueñez et al., 2017), Argentina (Bono Battistoni et al., 2016) and, recently, Uruguay (Greif et al., 2018). Symptoms of the disease in dogs vary greatly, less severe ones are: an increase in body temperature, corneal opacity, decreased appetite, increased respiratory rate and increased pulse (Aref et al., 2013; Colpo et al., 2005; Hosseininejad et al., 2007); in more severe cases, symptoms include nervous system-affecting signs that can be confused with rabies and may even include the death of the animal (Aquino et al., 2002).

The diagnosis of $T$. evansi continues to be difficult due to the intermittent parasitemia in the host and the cross-reactions that are generated in serological tests, making PCR the most appropriate laboratory technique for the specific detection of T. evansi in different hosts species (El-Metanawey et al., 2009; Fernández et al., 2009; Ramírez-Iglesias et al., 2011).

Advanced PCR techniques with high resolving power, such as PCR with subsequent High Resolution Melting analysis (PCR-HRM), is a tool that allows characterizing PCR products based on the dissociation (melting) of the double-stranded DNA by increasing the temperature (Dwight et al., 2011). It is a fast, highly sensitive and specific technique that allows the detection of genera, subgenera, species and populations of microorganisms (Hernández et al., 2014; Joste et al., 2018; Keatley et al., 2020).

The objective of this study is to report three autochthonous cases of canine trypanosomiasis caused by T. evansi, for the first time in the country, which were detected by using as a real-time PCR-HRM tool for the differential diagnosis of trypanosomatid species.

\section{Case report}

Between January 2018 and December 2019 three dogs from the Departments of San Pedro and Presidente Hayes (Figure 1), both departments in Paraguay, were referred to the "Centro para el Desarrollo de la Investigación Científica (CEDIC)" with clinical suspicion of Leishmaniasis. These three dogs resided in rural establishments dedicated to raise cattle and coexisted with other farm animals.

The three dogs were evaluated for clinical signs suggestive of leishmaniasis (weight loss, dermatitis, hair loss, mouth and skin ulcers, enlarged lymph nodes, onychogryphosis, arthritis, and conjunctivitis) by a veterinarian. In addition, each owner was asked about their dog's feeding habits and about any possible contact with wild mammals.

Samples of medullary aspirate, subcutaneous mass aspirate and peripheral blood from the three dogs were taken. Blood samples were collected using commercial tubes containing EDTA 


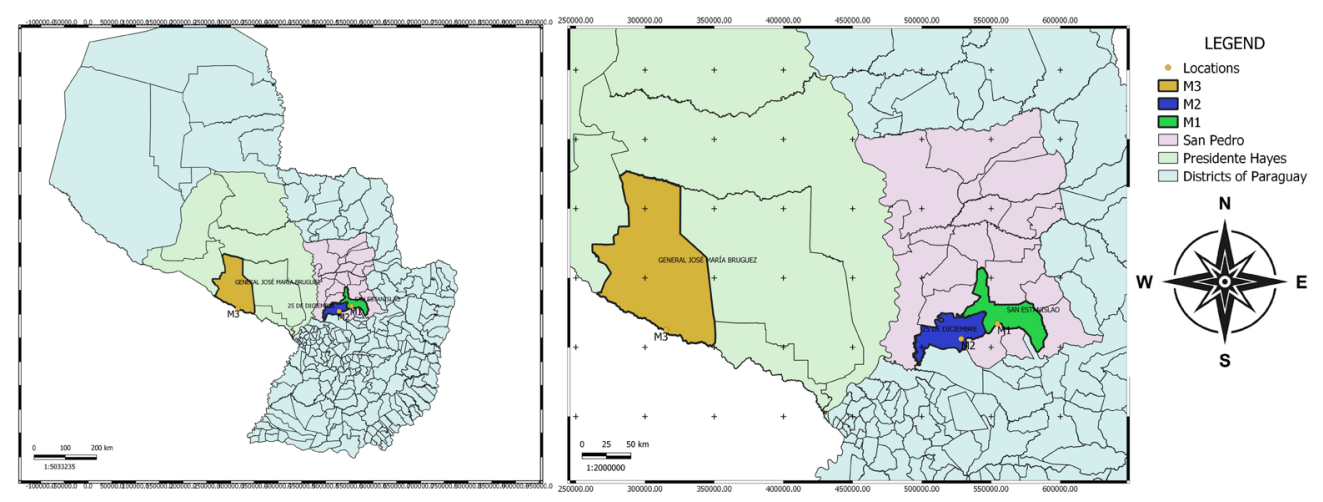

Figure 1. Geographical distribution of M1, M2 and M3 dogs diagnosed with Trypanosoma evansi in Paraguay.

as anticoagulant and stored at $4{ }^{\circ} \mathrm{C}$ until use. The medullary and subcutaneous mass aspirates were performed using a 21-gauge needle and $10 \mathrm{ml}$ disposable plastic syringe. The blood samples and the subcutaneous mass were used to prepare fixed colored smears while the medullary aspirates were diluted with $0.2 \mathrm{ml}$ lysis buffer for molecular analysis.

The peripheral blood and subcutaneous mass aspirate smears were air-dried, fixed in absolute methanol for three minutes, and stained with 10\% Giemsa (Biopak) for 40 minutes. Slides were analyzed under an optical microscope (Leica DM-500) at magnifications of 400X and 1000X.

Promastigotes of Leishmania (L.) infantum (MCAN/ES/92/BCN83) and Leishmania (V.) braziliensis (MHOM/BR/75/M2904) were cultured at $26^{\circ} \mathrm{C}$ in Schneider's Insect Medium (SigmaAldrich) supplemented with 10\% heat-inactivated fetal bovine serum (FBS) (Sigma-Aldrich). Trypanosoma cruzi epimastigotes (clone CL-B5) were grown at $28^{\circ} \mathrm{C}$ in liver infusion tryptose broth (LIT) supplemented with 10\% FBS (Sigma-Aldrich).

Extraction and purification of genomic DNA was completed using the GeneJET Genomic DNA Purification Kit (\#KO722 Thermo Scientific ${ }^{\circ}$ ), following the manufacturer's guidelines. The purity of the genetic material was evaluated using a (DS-11FX+ DeNovix ${ }^{\circ}$ ) spectrophotometer. For each of the positive controls, $2.5 \times 10^{6}$ of parasites in exponential growth phase were used. Medullary aspirate was used for the analysis of the samples under study.

In order to identify the trypanosomatids species, a fragment of the gen heat-shock protein 70 (hsp70) of 144bp was amplified, using the primers Fhsp7OF2 5'-GGAGAACTACGCGTACTCGATGAAG-3', and Rhsp70C 5'-TCCTTCGACGCCTCCTGGTTG-3' designed by Zampieri et al. (2016) for the discrimination of Leishmania species. Each PCR assay was made with a final volume of $25 \mu \mathrm{L}$, using $12.5 \mu \mathrm{L}$ of the mix (2x HRM PCR Master Mix-QIAGEN ${ }^{\circ}$ ), a final concentration of $50 \mathrm{ng} / \mu \mathrm{L}$ for the DNA template and both primers with a concentration of $0.5 \mu \mathrm{M}$.

The conditions for cycling were: initial denaturation at $95^{\circ} \mathrm{C}$ for 10 minutes, followed by 40 cycles of denaturation at $95^{\circ} \mathrm{C}$ for 10 seconds, annealing at $60^{\circ} \mathrm{C}$ for 30 seconds and elongation at $72{ }^{\circ} \mathrm{C}$ for 10 seconds. Following the real-time PCR, amplicon dissociation was immediately initiated by a melting step in the same machine. The range was set from $80^{\circ} \mathrm{C}$ to $90^{\circ} \mathrm{C}$, with a slope of $0.1 u C / s$, and $2 \mathrm{~s}$ intervals at each temperature. The assays were carried out using a real time thermal cycler (Rotor-Gene 6000 QIAGEN).

A high-resolution melt curve analysis was performed with the derivative of the raw data, after smoothing with the software 2.1.0 (Rotor-Gene-6000 QIAGEN ${ }^{\circ}$ ). DNA of T. cruzi, L. (L.) infantum and $L$. (V.) braziliensis, were used as positive control of the PCR.

In order to identify the species, a conventional PCR reaction was performed for the amplification and later sequencing of the internal transcribed spacers 1(ITS-1) gene from the specific rDNA for Trypanosoma spp., following the description by Njiru Z et al. (2005). Both products obtained were visualized in a 1.5\% agarose gel and subsequently purified (GeneJET PCR Purification Kit-Thermo Scientific ${ }^{\circ}$, following the manufacturer's instructions. The fragments obtained were sequenced by the Macrogen company (Geumcheon-gu, Seoul, Korea). 
The nucleotide sequences obtained were verified and purified using the software Bioedit version 7.0 (Hall, 1999). The nucleotide sequences were compared to those available in the public database using the algorithm Blastn of the NCBI BLAST.

Subsequently, a multiple alignment of the sequences obtained by applying the ClustalW algorithm was performed, comparing them with the sequences of the ITS-1 genes deposited in the NCBI GenBank.

Nucleotide sequence data reported in this paper are available in the GenBank ${ }^{\mathrm{TM}}$ database under the following accession numbers: MT490637.1, MT490638.1 and MT490639.1.

In this study, three cases of canine trypanosomiasis caused by T. evansi are reported in Paraguay for the first time; two of the dogs came from the Department of San Pedro and one from the Presidente Hayes Department (Figure 1). The parasitological findings of the trypomastigote forms were made by optical microscopy, and the species was molecularly confirmed by sequencing (Figure 2 ).

The three dogs which were studied are pets that reside in rural establishments dedicated to cattle raising, and that live in coexistence with other farm animals, mainly equines, outside the houses.

Main clinical signs which were observed in the present study are among those commonly observed in dogs infected with T. evansi, except for the subcutaneous masses present in M3. The clinical signs of each animal are detailed in Table 1.

Based on these findings, the molecular determination of the species of trypomastigotes was carried out by PCR and determined by analysis of the melting temperature (Tm) and the normalized curve of the hsp70 amplicons. The values of Tm for the positive controls as generated by the equipment were as follow: $L$. (L.) infantum: $\mathrm{Tm}=87.05 \pm 0.04$ OC; $L$. $(\mathrm{V}$.) braziliensis: $\mathrm{Tm}=87.87$ $\pm 0.01{ }^{\circ} \mathrm{C}$ and T. cruzi: $\mathrm{Tm}=85.25^{\circ} \mathrm{C} \pm 0.04$ (Figure 3). The positive control for each species generated unique melting temperature curves, which did not coincide with any of the three samples analyzed in this study. The Tm values obtained by HRM for the analyzed samples were: $\mathrm{M} 1=85.75^{\circ} \mathrm{C}, \mathrm{M} 2=85.69^{\circ} \mathrm{C}$ and $\mathrm{M} 3=85.70^{\circ} \mathrm{C}$ (Figure 3 ). Both DNA extractions and PCR-HRM were performed twice to confirm the results obtained.

To identify the Trypanosoma spp. species detected by HRM-PCR in the analyzed samples, fragments of the ITS-1 gene were sequenced after being amplified by conventional PCR.

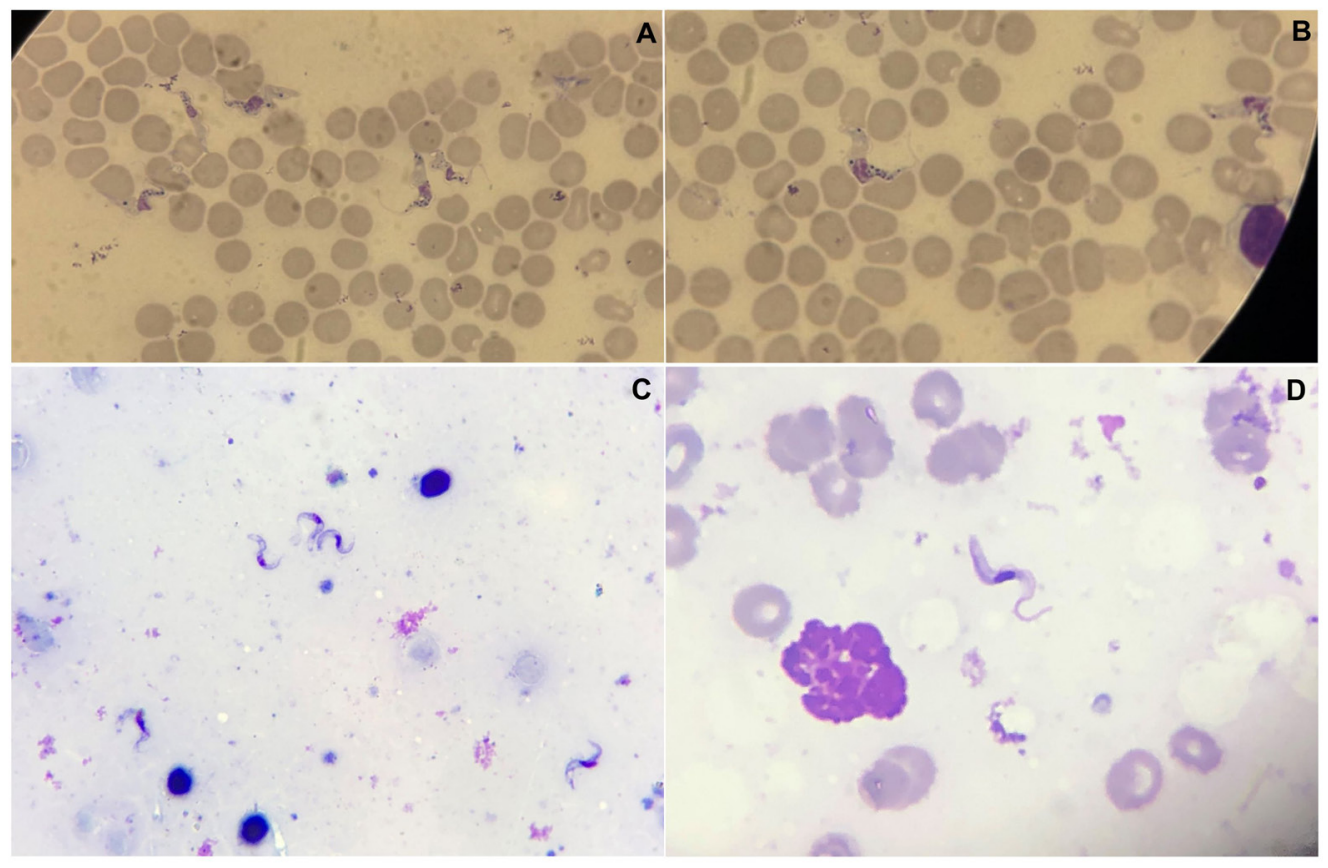

Figure 2. Microscopic images of trypomastigotes detected in peripheral blood from M1 (A), M2 (B) and detected on subcutaneous mass from M3 (C-D) at magnifications of 400X and 1000X. 
Table 1. Clinical findings of trypanosomiasis-associated disease in dogs from Paraguay.

\begin{tabular}{|c|c|c|c|c|}
\hline Identification & Breed & Sex & Age & Clinical Signs \\
\hline M1 & $\begin{array}{l}\text { Brazilian } \\
\text { Mastiff }\end{array}$ & Male & 4 & $\begin{array}{l}\text { Languishment, inappetence, intermittent fever, } \\
\text { lack of coordination in the posterior region, weight } \\
\text { loss, moderate superficial lymphadenopathy and } \\
\text { hyperproteinemia with moderate anemia. }\end{array}$ \\
\hline M2 & Rhodesian & Male & 3 & $\begin{array}{l}\text { Weight loss, superficial adenomegaly and pale } \\
\text { ocular and buccal mucosa. }\end{array}$ \\
\hline M3 & $\begin{array}{l}\text { Mixed } \\
\text { breed }\end{array}$ & Male & 3 & $\begin{array}{l}\text { Weight loss, moderate anemia, evident } \\
\text { superficial adenomegaly and the presence of two } \\
\text { subcutaneous masses at the right rib level, two } \\
\text { masses at the left rib level and one at the dorsal } \\
\text { level. The subcutaneous masses correspond to } \\
\text { a granulomatous inflammation composed of } \\
\text { lymphocytes, macrophages, neutrophils, and giant } \\
\text { cells with the presence of extracellular protozoa. }\end{array}$ \\
\hline
\end{tabular}
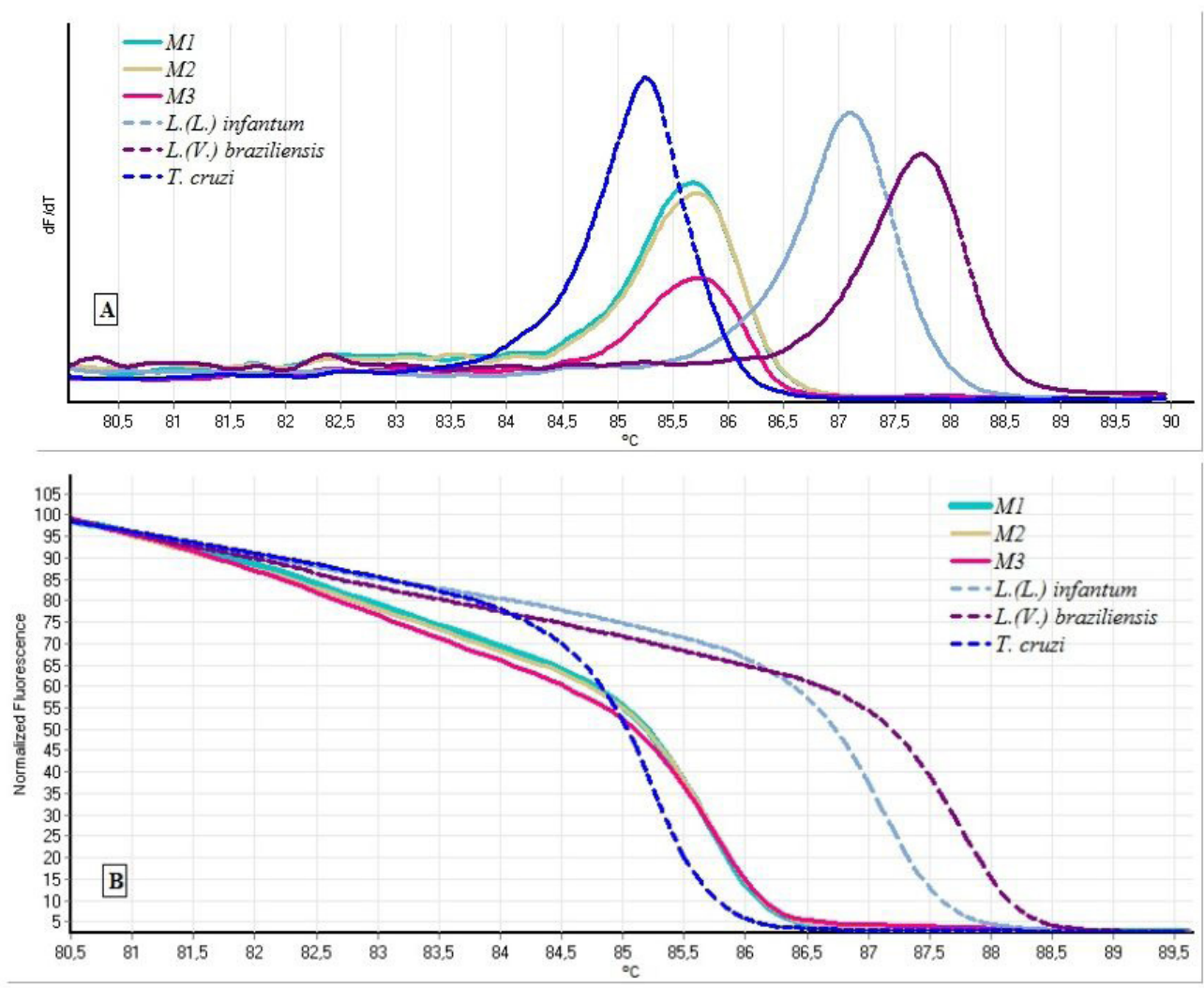

Figure 3. Detection and discrimination of the samples M1, M2 and M3, Trypanosoma cruzi, Leishmania infantum and Leishmania braziliensis. (A) Derivative melting curve peaks; (B) Normalized HRM plot of the heat-shock protein (hsp70) amplicon; each sample was performed in two independent experiments.

The sequences of the samples M1, M2 and M3 were deposited in the NCBI GenBank ${ }^{\mathrm{TM}}$ database (accession numbers MT490637.1, MT490638.1 and MT490639.1). The BLAST analysis result showed very close matches with T. evansi, (99.78\% similarity) for the 480 bp product sequences (data not shown). With the results obtained using molecular techniques, the presence of T. evansi in the three dogs in Paraguay was confirmed for the first time. 


\section{Discussion}

This is the first report of dogs infected with T. evansi in Paraguay as determined by using molecular techniques. The only two previous reports of the presence of the parasite in the country were found in horses in 1901 (Elmassian; 1901; Elmassian 1902; Elmassian \& Migone, 1903) and in capybaras in 1910 (Migone, 1910), both detected by optical microscopy.

In these three dog cases, the recorded clinical signs of the infection were similar to those of the previous reports of canine trypanosomiasis: weakness, fever, weight loss, anemia and lymphadenomegaly (Aquino et al., 1999; Bono Battistoni et al., 2016; Greif et al., 2018; JaimesDueñez et al., 2017). Although the granulomatous inflammation present in M3 has not been previously described in T. evansi infections, this could be related to the humoral immune response to the parasite. Other frequently reported clinical signs, such as keratitis and hemorrhage in the anterior eye chamber, could not be observed (Aquino et al., 1999).

In Latin America, there are only a few reports of natural infection by T. evansi in canines (CorreaSalgado et al., 2010; Greif et al., 2018; Jaimes-Dueñez et al., 2017; Stevens et al., 1989). In these cases, microscopic and serological techniques were used for the diagnosis of Trypanosoma spp. These few findings could be due to intermittent parasitaemia and cross-reactions with other microorganisms with similar and nonspecific symptoms, such as Leishmania spp., Ehrlichia spp. and Babesia spp., reducing the efficacy and specificity of these diagnostic tests (Gonzales et al., 2007).

For this reason, molecular techniques are considered the most appropriate ones for the specific determination of trypanosomatids or other parasitic infections that are difficult to diagnose, taking into account their high detection capacity and specificity. An experimental study in mice showed that real-time PCR is twice as sensitive for the detection of T. evansi than conventional parasitological techniques (Sharma et al., 2012). The most widely used molecular markers for the detection of this parasite are fragments of the ITS-1 (Eberhardt et al., 2014; Njiru et al., 2005; Sharma et al., 2012), variant surface glycoprotein (VSG) (Konnai et al., 2009) and 18S rRNA genes (Ereqat et al., 2020).

In this study, real-time PCR-HRM was used, based on other studies which reported the efficacy of this technique for the genotypic discrimination of bacteria, fungi and parasites of biomedical importance (Banowary et al., 2015; Goldschmidt et al., 2012; Kagkli et al., 2012; Lee et al., 2012). A fragment of the hsp70 gene was analyzed using primers initially developed to discriminate T. cruzi, T. brucei and different species of Leishmania because the samples were sent on clinical suspicion of leishmaniasis and the M2 specimen even obtained a positive result using the ELISA technique. It should be noted that this is the first report in which this pair of primers was used to detect and differentiate the presence of T. evansi by means of HRM analysis. The results which were obtained after sequencing confirmed that the dogs were infected with T. evansi and not with Leishmania spp., further demonstrating that locally available serological tests generate cross-reactions.

After correctly diagnosing the samples, all the specimens were treated with quinapyramine, a drug indicated for the treatment of trypanosomiasis, supplying them with two doses of $3.2 \mathrm{mg} / \mathrm{kg}$ subcutaneously every 30 days. All the dogs evolved clinically in a favorable way, and after eight months of treatment, no trypomastigotes were detected in any of them.

The three cases reported here correspond to acute T. evansi infections, which suggests active sources of transmission in the habitats where the animals reside. Although dogs are susceptible to an infection by this parasite, it is not something that occurs frequently and it is dependent on the proximity to local reservoirs which facilitate peroral infection or mechanical transmission by the bite of blood-sucking insects (Desquesnes, 2004).

There are no records of the insects' genera involved in the transmission of the parasite in the Departments of Presidente Hayes and San Pedro (Paraguay), locations where the dogs in this study belonged. However, there are records of Tabanus species in the Departments of Amambay, Cordillera and Alto Paraguay (Paraguay) and in the province of Formosa (Argentina), all of which are regions adjacent to San Pedro and Presidente Hayes respectively (Bachmann, 2012; Morrone \& Coscarón, 1998; Strickman, 1982). Most of the records for the country date back several decades, so it is a very outdated field of study, and there may currently be populations of Tabanus in the departments of Presidente Hayes and San Pedro due to the proximity to those registered populations. 
These first findings in the country encourage further research, mainly to determine the presence of the parasite in possible hosts and to elucidate the vectors implicated in its transmission.

\section{Conclusions}

The use of the PCR-HRM real-time methodology with the amplification of a fragment of the hsp70 gene and its subsequent confirmation by sequencing allowed reporting the presence of T. evansi in dogs from different regions in Paraguay for the first time in the country. Furthermore, this is the first report on the usage of this pair of primers as a molecular marker of the presence of T. evansi, and its usefulness as a differential diagnostic tool which can detect T. cruzi, Leishmania infantum and Leishmania braziliensis simultaneously was demonstrated.

\section{Ethics statement}

Dog owners formally consented to the study.

\section{Financial support}

This study was supported by the Organization for the Structural Convergence in the Mercosur Region (FOCEM, in Spanish. Grant number: FOCEM/MERCOSUR COF Nº3/11).

\section{Conflicts of interest}

All authors declare that there is no personal or economic interest for this paper.

\section{Authors' contributions}

ODSR - conception and design, methodology, analysis and interpretation of data, investigation, Writing-original draft. SF - conception, analysis and interpretation of data, investigation, Writingoriginal draft. MJT - conception and design, methodology, analysis and interpretation of data. PVA - methodology, investigation, writing-original draft. NRC - methodology, investigation, writingoriginal draft. MR - investigation, writing-original draft, writing-reviewing \& editing. CVG - Project administration, writing-reviewing \& editing, final approval.

\section{Availability of complementary results}

Body of Availability of complementary results.

The work was carried out at Centro para el Desarrollo de la Investigación Científica - CEDIC, Asunción, Paraguay.

\section{References}

Aquino, L. P. C. T., Machado, R. Z., Alessi, A. C., Santana, A. E., Castro, M. B., Marques, L. C., \& Malheiros, E. B. (2002). Hematological, biochemical and anatomopathological aspects of the experimental infection with Trypanosoma evansi in dogs. Arquivo Brasileiro de Medicina Veterinária e Zootecnia, 54(1), 8-18. http://dx.doi. org/10.1590/S0102-09352002000100002.

Aquino, L. P., Machado, R. Z., Alessi, A. C., Marques, L. C., de Castro, M. B., \& Malheiros, E. B. (1999). Clinical, parasitological and immunological aspects of experimental infection with Trypanosoma evansi in dogs. Memorias do Instituto Oswaldo Cruz, 94(2), 255-260. http://dx.doi.org/10.1590/s0074-02761999000200025. PMid:10224539.

Aref, M., Yasin, S. M., Bahear, W., Ghulam, Z., Hastie, L., Dennison, T., Schauwers, W., Büscher, P., \& Deborggraeve, S. (2013). Canine Trypanosoma evansi infection in Afghanistan. Veterinary Parasitology, 197(3-4), 638-641. http://dx.doi.org/10.1016/j.vetpar.2013.07.016. PMid:23993635.

Bachmann, A. O. (2012). A catalog of the types of Stratiomyidae, Tabanidae, Asilidae sensu lato, and Syrphidae (Insecta, Diptera) deposited in the Museo Argentino de Ciencias Naturales, Buenos Aires. Revista Del Museo Argentino de Ciencias Naturales, Nueva Serie, 14(1), 97-123. https://doi.org/10.22179/REVMACN.14.203

Banowary, B., Dang, V. T., Sarker, S., Connolly, J. H., Chenu, J., Groves, P., Ayton, M., Raidal, S., Devi, R., Vanniasinkam, T., \& Ghorashi, S. (2015). Differentiation of Campylobacter jejuni and Campylobacter coli Using Multiplex-PCR and High Resolution Melt Curve Analysis. PLOS One, 10(9), e0138808. http://dx.doi.org/10.1371/journal. pone.0138808. PMid:26394042. 
Bono Battistoni, M. F., Orcellet, V., Peralta, J. L., Marengo, R., Plaza, D., Brunini, A., Ruiz, M., Widenhorn, N., Sanchez, A., Monje, L., \& Cignetti, L. (2016). First report of Trypanosoma evansi in a canine in Argentina. Veterinary Parasitology, Regional Studies and Reports, 6, 1-3. http://dx.doi.org/10.1016/j.vprsr.2016.10.001. PMid:31014521.

Borst, P., Fase-Fowler, F., \& Gibson, W. C. (1987). Kinetoplast DNA of Trypanosoma evansi. Molecular and Biochemical Parasitology, 23(1), 31-38. http://dx.doi.org/10.1016/0166-6851(87)90184-8. PMid:3033499.

Brun, R., Hecker, H., \& Lun, Z. R. (1998). Trypanosoma evansi and T. equiperdum: Distribution, biology, treatment and phylogenetic relationship (a review). Veterinary Parasitology, 79(2), 95-107. http://dx.doi.org/10.1016/ S0304-4017(98)00146-0. PMid:9806490.

Colpo, C. B., Monteiro, S. G., Stainki, D. R., Colpo, E. T. B., \& Henriques, G. B. (2005). Infecção natural por Trypanosoma evansi em cães. Ciência Rural, 35(3), 717-719. http://dx.doi.org/10.1590/S0103-84782005000300038.

Correa-Salgado, A. M., Pacheco de Araujo, F. A., \& Cañón-Franco, W. A. (2010). Infección Natural por Trypanosoma evansien Canino, Manizales - Colombia : Caso clínico. Revista Ibero-latinoamericana de Parasitología, 69(1), 98-100.

Desquesnes, M. (2004). Livestock Trypanosomoses and their vectors in Latin America (174 p.). World Organization for Animal Health.

Desquesnes, M., Dargantes, A., Lai, D. H., Lun, Z. R., Holzmuller, P., \& Jittapalapong, S. (2013a). Trypanosoma evansi and surra: A review and perspectives on transmission, epidemiology and control, impact, and zoonotic aspects. BioMed Research International, 321237, 321237. http://dx.doi.org/10.1155/2013/321237. PMid:24151595.

Desquesnes, M., Holzmuller, P., Lai, D. H., Dargantes, A., Lun, Z. R., \& Jittaplapong, S. (2013b). Trypanosoma evansi and surra: A review and perspectives on origin, history, distribution, taxonomy, morphology, hosts, and pathogenic effects. BioMed Research International, 2013, 1-22. http://dx.doi.org/10.1155/2013/194176. PMid:24024184.

Dwight, Z., Palais, R., \& Wittwer, C. T. (2011). uMELT: Prediction of high-resolution melting curves and dynamic melting profiles of PCR products in a rich web application. Bioinformatics (Oxford, England), 27(7), 1019-1102. http://dx.doi.org/10.1093/bioinformatics/btr065. PMid:21300699.

Eberhardt, A. T., Monje, L. D., Zurvera, D. A., \& Beldomenico, P. M. (2014). Detection of Trypanosoma evansi infection in wild capybaras from Argentina using smear microscopy and real-time PCR assays. Veterinary Parasitology, 202(3-4), 226-233. http://dx.doi.org/10.1016/j.vetpar.2014.02.043. PMid:24636712.

Elmassian, M. (1901). Mal de caderas. In Conférence Faite au Conseil National d'Hygiène le 19 mai. Anales de la Universidad Nacional: Vol. 16. Universidad Nacional.

Elmassian, M. (1902). Mal de caderas, flagelosis paresiante de los equideos. Revista de la Sociedad Médica Argentina, 10(53), 122-148.

Elmassian, M., \& Migone, L. E. (1903). Sur le mal de caderas ou flagellose parésiante des équidés sud-américains. Annales de l'Institut Pasteur, 17(4), 241-267.

El-Metanawey, T. M., El-Beih, N. M., El-Aziz, M. M., Hassanane, M. S., \& El-Aziz, T. H. (2009). Comparative studies on diagnosis of Trypanosoma evansi in experimentally infected goats. Global Veterinaria, 3, 348-353.

Ereqat, S., Nasereddin, A., Al-Jawabreh, A., Al-Jawabreh, H., Al-Laham, N., \& Abdeen, Z. (2020). Prevalence of Trypanosoma evansi in livestock in Palestine. Parasites \& Vectors, 13(1), 21. http://dx.doi.org/10.1186/s13071020-3894-9. PMid:31931864.

Fernández, D., González-Baradat, B., Eleizalde, M., González-Marcano, E., Perrone, T., \& Mendoza, M. (2009) Trypanosoma evansi: A comparison of PCR and parasitological diagnostic tests in experimentally infected mice. Experimental Parasitology, 121(1), 1-7. http://dx.doi.org/10.1016/j.exppara.2008.09.013. PMid:18848544.

Fowler, M. E. (2010). Parasites. In M.E. Fowler. Medicine and surgery of Camelids (chap. 8, pp. 231-269). WileyBlackwell. http://dx.doi.org/10.1002/9781118785706.

Franciscato, C., Lopes, S. T. A., Teixeira, M. M. G., Monteiro, S. G., Wolkmer, P., Garmatz, B. C., \& Paim, C. B. (2007) Cão naturalmente infectado por Trypanosoma evansi em Santa Maria, RS, Brasil. Ciência Rural, 37(1), 288-291. http://dx.doi.org/10.1590/S0103-84782007000100049.

Franke, C. R., Greiner, M., \& Mehlitz, D. (1994). Investigations on naturally occurring Trypanosoma evansi infections in horses, cattle, dogs and capybaras (Hydrochaeris hydrochaeris) in Pantanal de Poconé (Mato Grosso, Brazil). Acta Tropica, 58(2), 159-169. http://dx.doi.org/10.1016/0001-706X(94)90055-8. PMid:7887341.

Goldschmidt, P., Degorge, S., Che Sarria, P., Benallaoua, D., Semoun, O., Borderie, V., Laroche, L., \& Chaumeil, C. (2012). New Strategy for Rapid Diagnosis and Characterization of Fungal Infections: The Example of Corneal Scrapings. PLoS One, 7(7), e37660. http://dx.doi.org/10.1371/journal.pone.0037660. PMid:22768289.

Gonzales, J. L., Chacon, E., Miranda, M., Loza, A., \& Siles, L. M. (2007). Bovine trypanosomosis in the Bolivian Pantanal. Veterinary Parasitology, 146(1-2), 9-16. http://dx.doi.org/10.1016/j.vetpar.2007.02.010. PMid:17374452.

Greif, G., Faral-Tello, P., Scardoelli Vianna, C., Hernandez, A., Basmadjian, Y., \& Robello, C. (2018). The first case report of trypanosomiasis caused by Trypanosoma evansi in Uruguay. Veterinary Parasitology, Regional Studies and Reports, 11, 19-21. http://dx.doi.org/10.1016/j.vprsr.2017.11.002. PMid:31014612.

Hall, T. A. (1999). BioEdit: A user-friendly biological sequence alignment editor and analysis program for Windows 95/98/NT. Nucleic Acids Symposium Series, 41, 95-98.

Hernández, C., Alvarez, C., González, C., Ayala, M. S., León, C. M., \& Ramírez, J. D. (2014). Identification of six New World Leishmania species through the implementation of a High-Resolution Melting (HRM) genotyping assay. Parasites \& Vectors, 7(1), 501. http://dx.doi.org/10.1186/s13071-014-0501-y. PMid:25394418. 
Herrera, H. M., Norek, A., Freitas, T. P. T., Rademaker, V., Fernandes, O., \& Jansen, A. M. (2005). Domestic and wild mammals infection by Trypanosoma evansi in a pristine area of the Brazilian Pantanal region. Parasitology Research, 96(2), 121-126. http://dx.doi.org/10.1007/s00436-005-1334-6. PMid:15824901.

Hoare, C. A. (1965). Vampire bats as vectors and hosts of equine and bovine trypanosomes. Acta Tropica, 22(3), 204-216. PMid:4379528.

Hosseininejad, M., Shirani, D., Nabian, S., Nassiri, S. M., \& Mazaheri, R. (2007). Trypanosoma evansi in three dogs in Iran. Comparative Clinical Pathology, 16(1), 69-71. http://dx.doi.org/10.1007/s00580-006-0642-2.

Jaimes-Dueñez, J., Triana-Chávez, O., Valencia-Hernández, A., Sánchez-Arévalo, D., Poche-Ceballos, A., Ortíz-Álvarez, J., \& Mejía-Jaramillo, A. M. (2017). Molecular diagnosis and phylogeographic analysis of Trypanosoma evansi in dogs (Canis lupus familiaris) suggest an epidemiological importance of this species in Colombia. Preventive Veterinary Medicine, 139(Pt A), 82-89. http://dx.doi.org/10.1016/j.prevetmed.2017.02.007. PMid:28364836.

Joste, V., Kamaliddin, C., Kendjo, E., Hubert, V., Argy, N., \& Houzé, S. (2018). Distinction of Plasmodium ovale wallikeri and Plasmodium ovale curtisi using quantitative Polymerase Chain Reaction with High Resolution Melting revelation. Scientific Reports, 8(1), 300. http://dx.doi.org/10.1038/s41598-017-18026-1. PMid:29321578.

Kagkli, D. M., Folloni, S., Barbau-Piednoir, E., Van den Eede, G., \& Van den Bulcke, M. (2012). Towards a pathogenic escherichia coli detection platform using multiplex SYBR ${ }^{\circledR}$ green Real-Time PCR methods and high resolution melting analysis. PLoS One, 7(6), e39287. http://dx.doi.org/10.1371/journal.pone.0039287. PMid:22761753.

Keatley, S., Botero, A., Fosu-Nyarko, J., Pallant, L., Northover, A., \& Thompson, R. C. A. (2020). Species-level identification of trypanosomes infecting Australian wildlife by High-Resolution Melting-Real Time Quantitative Polymerase Chain Reaction (HRM-qPCR). International Journal for Parasitology. Parasites and Wildlife, 13, 261-268. http://dx.doi.org/10.1016/j.ijppaw.2020.11.003. PMid:33294365.

Konnai, S., Mekata, H., Mingala, C. N., Abes, N. S., Gutierrez, C. A., Herrera, J. R. V., Dargantes, A. P., Witola, W. H., Cruz, L. C., Inoue, N., Onuma, M., \& Ohashi, K. (2009). Development and application of a quantitative realtime PCR for the diagnosis of Surra in water buffaloes. Infection, Genetics and Evolution, 9(4), 449-452. http:// dx.doi.org/10.1016/j.meegid.2009.01.006. PMid:19460309.

Lee, T.-H., Wu, T.-S., Tseng, C.-P., \& Qiu, J. T. (2012). High-resolution melting molecular signatures for rapid identification of human Papillomavirus genotypes. PLoS One, 7(8), e42051. http://dx.doi.org/10.1371/journal. pone.0042051. PMid:22916117.

Lun, Z.R., \& Desser, S. S. (1995). Is the broad range of hosts and geographical distribution of Trypanosoma evansi attributable to the loss of Maxicircle Kinetoplast DNA? Parasitology Today (Personal Ed.), 11(4), 131-133. http:// dx.doi.org/10.1016/0169-4758(95)80129-4. PMid:15275353.

Migone, L. E. (1910). Le role des carpinchos comme reservoir de virus dans la conservation du Mal de Caderas. Bulletin de la Société de Pathologie Exotique, 3, 524-525.

Morrone, J. J., \& Coscarón, S. (1998). Biodiversidad de artrópodos argentinos: una perspectiva biotaxonómica. Ediciones Sur: Buenos Aires, Argentina.

Muñoz, K., \& Chávez, A. (2001). Trypanosoma evansi Isolated from Capybara (Hidrochaeris hidrochaeris). Memorias do Instituto Oswaldo Cruz, 96(7), 945-946. http://dx.doi.org/10.1590/S0074-02762001000700009. PMid:11685258.

Njiru, Z. K., Constantine, C. C., Guya, S., Crowther, J., Kiragu, J. M., Thompson, R. C., \& Dávila, A. M. (2005). The use of ITS1 rDNA PCR in detecting pathogenic African trypanosomes. Parasitology Research, 95(3), 186-192. http://dx.doi.org/10.1007/s00436-004-1267-5. PMid:15619129.

Nunes, V. L. B., \& Oshiro, E. T. (1990). Trypanosoma (Trypanozoon) evansi in the coati from the Pantanal reigon of Mato Grosso do Sul State, Brazil. Transactions of the Society of Tropical Medicine and Hygiene, 84(5), 692. http://dx.doi.org/10.1016/0035-9203(90)90148-8. PMID: 2278072.

Ramírez-Iglesias, J. R., Eleizalde, M. C., Gómez-Piñeres, E., \& Mendoza, M. (2011). Trypanosoma evansi: A comparative study of four diagnostic techniques for trypanosomosis using rabbit as an experimental model. Experimental Parasitology, 128(1), 91-96. http://dx.doi.org/10.1016/j.exppara.2011.02.010. PMid:21320490.

Sharma, P., Juyal, P. D., Singla, L. D., Chachra, D., \& Pawar, H. (2012). Comparative evaluation of real time PCR assay with conventional parasitological techniques for diagnosis of Trypanosoma evansi in cattle and buffaloes. Veterinary Parasitology, 190(3-4), 375-382. http://dx.doi.org/10.1016/j.vetpar.2012.07.005. PMid:22858228.

Silva, R. A. M. S., Arosemena, N. A. E., Herrera, H. M., Sahib, C. A., \& Ferreira, M. S. J. (1995). Outbreak of trypanosomosis due to Trypanosoma evansi in horses of Pantanal Mato-grossense, Brazil. Veterinary Parasitology, 60(1-2), 167-171. http://dx.doi.org/10.1016/0304-4017(94)00757-4. PMid:8644453.

Stevens, J. R., Nunes, V. L. B., Lanham, S. M., \& Oshiro, E. T. (1989). Isoenzyme characterization of Trypanosoma evansi isolated from capybaras and dogs in Brazil. Acta Tropica, 46(4), 213-222. http://dx.doi.org/10.1016/0001706X(89)90021-1. PMid:2571248.

Strickman, D. (1982). Notes on Tabanidae (Diptera) from Paraguay. Journal of Medical Entomology, 19(4), 399-402. https://doi.org/10.1093/jmedent/19.4.399

Woo, P. T. K. (1977). Salivarian trypanosomes producing disease in livestock outside of sub-Saharan Africa. In J.P. Kreier.ParasiticProtozoa (pp. 269-296). Academic Press. http://dx.doi.org/10.1016/B978-0-12-426001-6.50013-X.

Zampieri, R. A., Laranjeira-Silva, M. F., Muxel, S. M., Stocco de Lima, A. C., Shaw, J. J., \& Floeter-Winter, L. M. (2016). High resolution melting analysis targeting HSP7O as a fast and efficient method for the discrimination of Leishmania species. PLoS Neglected Tropical Diseases, 10(2), e0004485. http://dx.doi.org/10.1371/journal, pntd.0004485. PMid:26928050. 